\title{
Evidence for a major role of inhibin in the feedback control of FSH in the male rat*
}

\author{
G. F. Weinbauer†, J. M. S. Bartlett $\uparrow$, U. Fingscheidt $\uparrow$, C. G. Tsonis $\ddagger$, \\ D. M. de Kretser§ and E. Nieschlag†
}

†Max Planck Clinical Research Unit for Reproductive Medicine, and Institute for Reproductive Medicine of the University, Steinfurter Str. 107, 4400 Münster, West Germany; $\vdots$ Department of Obstetrics and Gynaecology, University of Edinburgh, 37 Chalmers Street, Edinburgh EH3 9EW, UK; and §Department of Anatomy, Monash University, Clayton, Victoria 3168, Australia

\begin{abstract}
Summary. Adult rats (16-18/group) received a single intratesticular injection of 25,100 or $400 \mu \mathrm{l}$ glycerol solution $(7: 3$ in distilled water, $v / v)$. Half of the rats in each group were given implants of testosterone, a testosterone-filled Silastic capsule $(1.5 \mathrm{~cm}$ length) to provide serum values of testosterone within the normal range. After 1 week all animals were killed by decapitation. Serum concentrations of gonadotrophins, testosterone and immunoactive inhibin as well as testicular concentrations of testosterone and bioactive inhibin were determined. Testicular histology was studed in Paraplastembedded tissue stained with PAS and haematoxylin-eosin. Glycerol treatment caused a dose-dependent ablation of spermatogenesis in a distinct area around the site of injection. Serum concentrations of FSH increased proportionally with increasing spermatogenic damage while serum $\mathrm{LH}$ and testosterone remained unaltered except with the highest glycerol dose. The rise in serum FSH was significantly correlated with serum $(r=-0.70, P<0.001)$ and testicular $(r=-0.66, P<0.001)$ concentrations of inhibin. A less pronounced correlation was found between LH and serum inhibin $(r=0.48)$. No correlation was found between the concentrations of LH and testicular inhibin or between serum concentrations of FSH and serum testosterone in the 25 and $100 \mu \mathrm{l}$ groups. Maintenance of low to normal serum testosterone concentrations by means of Silastic implants blocked the elevation of FSH in glycerol-treated animals but failed to affect significantly serum FSH in untreated rats. In all testosterone treated rats testicular inhibin concentrations were markedly reduced in the presence of lowered concentrations (7-14\%) of testicular testosterone and unaltered serum FSH concentrations.

These findings indicate that (i) inhibin is involved in the in-vivo regulation of FSH secretion in the adult male rat, (ii) testicular inhibin content, at least in part, may be regulated at the testicular level, and (iii) serum inhibin concentrations to some extent reflect the extent of damage to spermatogenesis and Sertoli cells.
\end{abstract}

Keywords: inhibin; testosterone; FSH; feedback; testis; rat

\section{Introduction}

The synthesis and release of pituitary hormones is under the feedback control of gonadal hormones. While it is well established that testosterone is the feedback hormone for LH in the male, the testicular control of FSH secretion appears to be mediated by testosterone and a semini- 
ferous tubule factor, inhibin. Both testosterone and gonadal extracts containing inhibin activity have been shown to suppress serum concentrations of FSH (see de Kretser et al., 1983, for review). To date, however, the relative importance of testosterone and inhibin in the feedback control of FSH in the male rat remains unclear. Testosterone has been shown to suppress serum FSH in the intact and castrated male rat (Swerdloff \& Walsh, 1973; Steiner et al., 1982). Disruption of spermatogenesis by $\mathrm{X}$-irradiation, treatment with $\alpha$-chlorohydrin, heat, ligation of the efferent ducts or experimentally induced vitamin A deficiency has been associated with selective elevation of serum FSH values in spite of unaltered serum concentrations of LH and testosterone (Baine \& Keene, 1975; Morris \& Jackson, 1978; Collins et al., 1978; Huang et al., 1984), while significant elevation of both LH and FSH following induction of severe testicular damage has been observed (Rich et al., 1979). Under the conditions of selective elevation of serum FSH concentrations it would appear that the normal serum values of testosterone do not prevent the rise in FSH concentration suggesting that reduction in the production and/or secretion of inhibin caused elevation of FSH. The inhibin concept of FSH feedback regulation has received much support since the isolation and characterization of the inhibin molecule (Mason et al., 1985; Robertson et al., 1985).

In the present investigation, the intratesticular injection of glycerol was used as the experimental approach for studying FSH feedback regulation by the testis. After injection of glycerol, 3 morphologically distinct types of seminiferous tubules are present within the same testis, i.e. tubules with normal spermatogenesis, tubules containing spermatogonia and Sertoli cells only, and tubules devoid of all cellular elements (Weinbauer et al., 1985). The proportions of the morphological types of seminiferous tubules within the testis depend on the dose of glycerol injected and serum FSH concentrations quantitatively reflect the extent of spermatogenic inhibition (Weinbauer $e t$ al., 1987). Therefore, in the present investigation, the gonadotrophic response to the intratesticular injection of glycerol, which induces spermatogenic ablation in a dose-dependent manner, was correlated with the serum concentrations of testosterone and inhibin and the testicular levels of testosterone and inhibin in the presence and absence of constant serum values of testosterone provided by Silastic implants.

\section{Material and Methods}

Adult, male Sprague-Dawley rats (300-350 g) were purchased from the Central Institute for Laboratory Animal Breeding (Hannover, West Germany) and housed 2-3/cage under controlled environmental conditions with free access to pelleted food and tap water.

Experimental design. The preparation and intratesticular injection of the glycerol solution (7:3 in distilled water, v/v) was performed as previously described (Weinbauer et al., 1985). Glycerol (87\% pure) was obtained from Merck (Darmstadt, West Germany; No. 4091). Groups of 16-18 rats remained untreated or received a single intratesticular injection of 25,100 or $400 \mu$ lglycerol solution in both testes. On the same day, half of the rats in each group received a subcutaneous testosterone-filled Silastic capsule (i.d. 0.132 in, o.d. 0.183 in; Dow Corning, Düsseldorf, West Germany) $1.5 \mathrm{~cm}$ in length. After 7 days all rats were anaesthetized with ether and, following decapitation, trunk blood was collected. The testes were excised and weighed. One testis was processed for determination of intratesticular testosterone and inhibin content. For histological examination the contralateral testis was fixed by immersion in Bouin's fluid, dehydrated in ethanol and embedded in Paraplast (Lancer, Oxford, UK). Sections ( $5 \mu \mathrm{m}$ ) were cut and stained with periodic acid-Schiff's base and haematoxylin-eosin.

Serum hormones. Testosterone was determined in unchromatographed serum using a previously validated radioimmunoassay (Schürmeyer et al., 1983). The minimal detectable concentration was $0.23 \mathrm{ng} / \mathrm{ml}$ and the intra- and interassay coefficients of variation were $7.3 \%$ and $13.8 \%$, respectively. $\mathrm{LH}$ and FSH were measured by doubleantibody radioimmunoassays using reagents kindly provided by NIADDK (Bethesda, MD, USA). The reagents used were LH-I-6 and FSH-I-6 as tracer, LH-RP-1 and FSH-RP-2 as standard and anti-rLH-S-9 and anti-FSH-I-11 antisera. The limits of detection were $0.156 \mathrm{ng} \mathrm{LH} /$ tube and $0.312 \mathrm{ng} \mathrm{FSH} /$ tube. For each hormone all samples were analysed in a single assay and the intra-assay coefficient of variation was $6 \%$ for $\mathrm{LH}$ and $4 \%$ for FSH.

Inhibin was measured in a double-antibody radioimmunoassay system validated for male rat serum by Robertson et al., (1988). Briefly, purified bovine inhibin of $M_{\mathrm{r}} 31000$ was used as tracer. A rat ovarian extract served as inhibin standard. The inhibin unitage of this standard preparation (JU3) was based on its in-vitro bioactivity. The antiserum (As $\$ 1989$ ) against the $M_{\mathrm{r}} 31000$ inhibin was raised in a rabbit. Cross-reactivity with bovine activin-A, bovine $\alpha$ and $\beta$-subunit of $M_{\mathrm{r}} 31000$ inhibin, bovine MIS, human TGF- $\beta$ and human and rat gonadotrophin was $<0.5 \%$ 
(Robertson et al., 1988). The assay sensitivity was $0.1 \mathrm{U} / \mathrm{ml}$. All samples were analysed in a single assay. The intra-assay variation was $4 \cdot 3 \%$.

Testicular testosterone and inhibin. Testes were homogenized in $1 \mathrm{ml} / \mathrm{g}$ of $0 \cdot 1 \mathrm{M}$-phosphate-buffered saline ( $\mathrm{pH} 7 \cdot 4$ ) and centrifuged at $100000 \mathrm{~g}$ for $60 \mathrm{~min}$ at $4^{\circ} \mathrm{C}$. Then $100 \mu \mathrm{l}$ of the supernatant were extracted with ether and the extract was analysed for testosterone as described above. Before determination of inhibin activity, the supernatants were treated with charcoal $\left(1 \%\right.$, Norit A) for $30 \mathrm{~min}$ at $4^{\circ} \mathrm{C}$ and then centrifuged at $2500 \mathrm{~g}$. Inhibin activity in the supernatant was measured in the in-vitro-bioassay system described by Tsonis et al. (1986). This bioassay system is based upon the inhibition of FSH release from cultured sheep pituitary cells. Ovine rete testis fluid was used as inhibin reference standard. All samples were bio-assayed in duplicate at 3 dilutions. The minimum sensitivity of the bioassay was $0.05 \mathrm{U} / \mathrm{ml}$. All samples were run in one assay. The intra-assay variation was $8.2 \%(\lambda=0.082)$. Dose-response curves were parallel.

Statistical evaluation. Data were analysed by two-way analysis of variance followed by Tukey's multiple comparison test. Correlation analysis was performed on serum and testicular hormone measurements. The level of significance was set at 5\%. Values are given as mean \pm s.e.m. All computations were performed using the STSC statistical program (STSC Inc., Rockville, MD, USA).

\section{Results}

\section{Testicular weight}

Intratesticular injection of glycerol reduced testicular weight $(\mathrm{g})$ in a dose-dependent manner (control: $1.88 \pm 0.03 ; 25 \mu \mathrm{l}: 1.67 \pm 0.05 ; 100 \mu \mathrm{l}: 1.45 \pm 0.05 ; 400 \mu \mathrm{l}: 0.99 \pm 0.03$ ). Testis weights in rats bearing a testosterone-implant, irrespective of whether they received glycerol treatment, were significantly lower $(P<0.05)$ than in groups without testosterone implants except for the highest dose of glycerol (control: $1.69 \pm 0.03 ; 25 \mu \mathrm{l}: 1.50 \pm 0.03 ; 100 \mu \mathrm{l}: 1 \cdot 26: \pm 0.03 ; 400 \mu \mathrm{l}: 1.03 \pm 0.02$ ).

\section{Testicular histology}

The histological appearance of testes injected with $25-400 \mu \mathrm{l}$ glycerol was similar to that reported previously using an identical treatment regimen (Weinbauer et al., 1987). At all doses of glycerol seminiferous tubules with normal spermatogenesis, tubules containing only spermatogonia and Sertoli cells, and tubules devoid of any cellular elements were present. Seminiferous tubule morphology of rats receiving a testosterone implant was, in qualitative terms, indistinguishable from the corresponding treatment groups.

\section{Serum hormones}

The hormone concentrations are depicted in Fig. 1. No significant differences in serum concentrations of $\mathrm{LH}$ and testosterone were found between untreated rats and rats injected with 25 or $100 \mu \mathrm{l}$ glycerol, while in rats treated with $400 \mu$ l glycerol, LH concentrations were grossly elevated and concentrations of testosterone were markedly reduced $(P<0.01)$. Exogenous testosterone significantly reduced LH concentrations when compared to untreated rats $(P<0.05)$ and blocked the $\mathrm{LH}$ rise in the group treated with $400 \mu \mathrm{l}$ glycerol. Serum concentrations of testosterone among testosterone-treated groups were lower in the 25 and $400 \mu$ l groups relative to the testosteroneimplanted controls but not statistically different from the untreated control group.

Serum concentrations of FSH were $28 \%, 45 \%$ and $326 \%$ higher in groups injected with $25 \mu$, $100 \mu \mathrm{l}$ and $400 \mu \mathrm{l}$ glycerol, respectively, when compared to the untreated control group $(P<0 \cdot 005)$. Concentrations of FSH with the highest dose of glycerol reached the range of values found in castrated rats $(24-46 \mathrm{ng} / \mathrm{ml}$; Weinbauer et al., 1987). The testosterone implants prevented this rise of FSH but had no significant suppressive effect on concentrations of FSH when compared to untreated rats.

Serum concentration of inhibin in the control group was $3.61 \pm 0.20 \mathrm{U} / \mathrm{ml}$. Inhibin levels declined to $90 \%, 75 \%$ and $43 \%$ with $25 \mu \mathrm{l}, 100 \mu \mathrm{l}(P<0.05)$ and $400 \mu \mathrm{l}(P<0.01)$ of glycerol, 


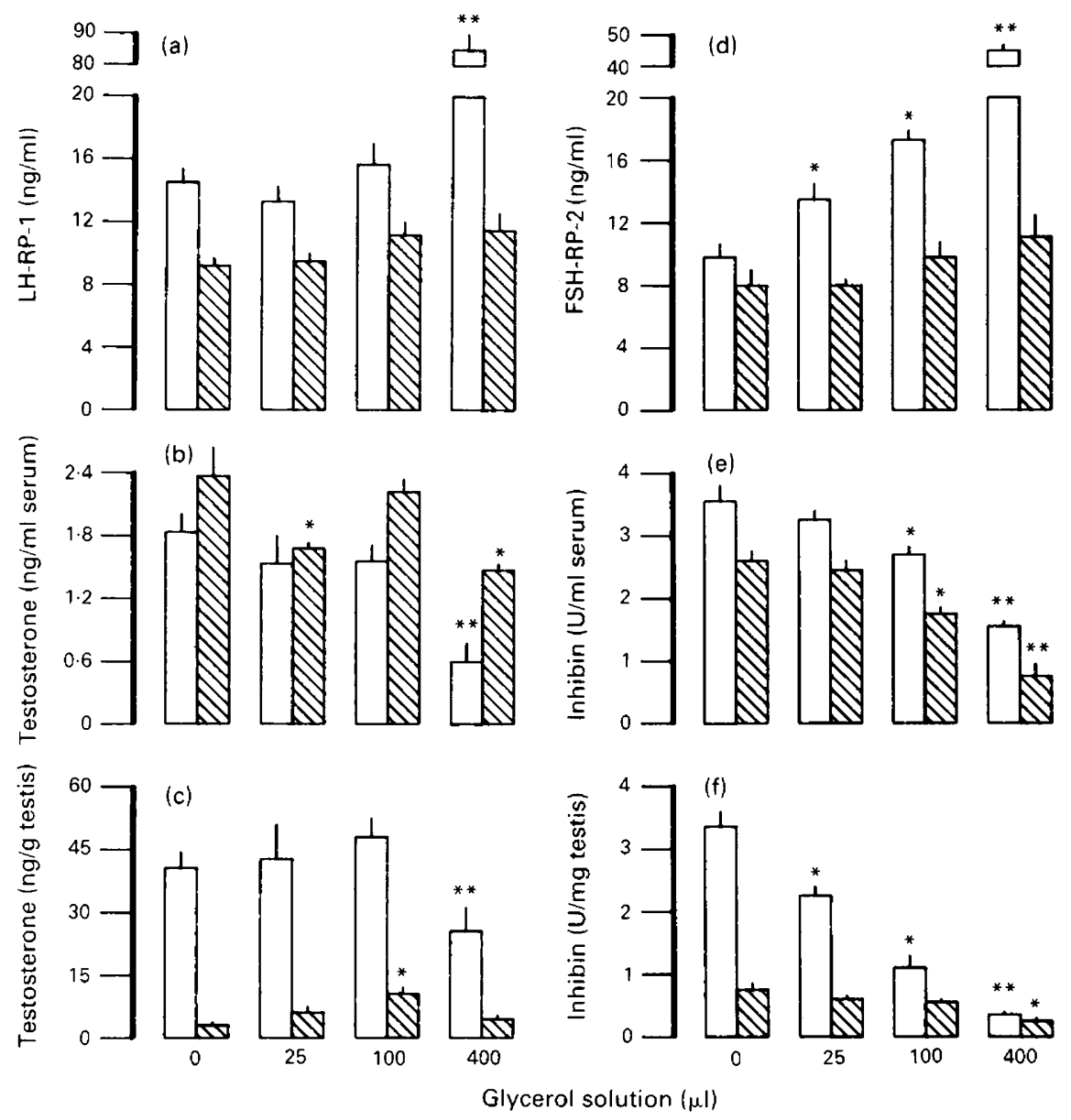

Fig. 1. Concentrations of serum and testicular hormones (mean \pm s.e.m.) of rats 1 week after intratesticular injection of glycerol. Hatched bars indicate testosterone supplementation starting on Day $0 .{ }^{*} P<0.05$ and ${ }^{* *} P<0.01$ compared with respective control group.

respectively. Testosterone treatment alone reduced serum inhibin to $3 \cdot 13 \pm 0 \cdot 13 \mathrm{U} / \mathrm{ml}(87 \%$ of control). Combined treatment with glycerol $(25,100$ or $400 \mu 1)$ and testosterone lowered inhibin values to $93.5 \%, 71 \%$ and $45 \%$, respectively, when compared to the group receiving testosterone alone.

\section{Testicular testosterone and inhibin}

Testicular concentrations of hormones are shown in Fig. 1. Intratesticular concentrations of testosterone did not vary between control, 25 and $100 \mu$ glycerol-treated groups but were significantly lowered with $400 \mu \mathrm{l}$ glycerol $(P<0 \cdot 05)$. Administration of testosterone markedly decreased intratesticular testosterone values. In the group receiving testosterone treatment alone, testicular testosterone concentration was, on average, $5.9 \%$ of untreated control values. In groups treated with 25 and $100 \mu \mathrm{l}$ glycerol and receiving a testosterone-implant, the concentration of testicular testosterone was $1 \cdot 8-3 \cdot 3$-fold higher than in the respective group receiving testosterone alone.

Testicular inhibin concentration decreased in a dose-dependent fashion with increasing doses of glycerol. Inhibin concentrations were reduced to $76 \%, 32 \%$ and $10 \%$ of control values in groups 
treated with $25 \mu \mathrm{l}, 100 \mu \mathrm{l}$ and $400 \mu \mathrm{l}$ glycerol, respectively. Administration of testosterone markedly and uniformly suppressed testicular concentrations of inhibin in all testosterone-treated groups by more than $75 \%$ in the presence of serum FSH values not significantly different from those of untreated controls. Compared to the group treated with testosterone alone, glycerol at doses of 25 , 100 and $400 \mu \mathrm{l}$ lowered testicular inhibin to $76 \%, 70 \%$ and $30 \%$, respectively, in the testosteronetreated groups.

\section{Correlations between serum and testicular hormones}

The following correlation coefficients were obtained from rats without testosterone implants $(\mathrm{N}=26)$. Significant correlations $(P<0.001)$ were found for both $\mathrm{LH}$ and FSH with serum testosterone $(r=-0.60$, and $r=-0.63)$, serum inhibin $(r=-0.78$ and $r=-0.88)$ or testicular inhibin ( $r=-0.61$ and $r=-0.72$ ). For evaluation of the relative importance of testosterone and inhibin in the regulation of FSH, the correlation coefficients were also calculated for those glyceroltreated groups without a statistically significant change of serum concentrations of testosterone and $\mathrm{LH}(25 \mu \mathrm{l}$ and $100 \mu \mathrm{l}$ groups). A significant negative correlation $(P<0.001)$ was found between serum FSH and serum $(r=-0.70)$ or testicular $(r=-0.66, P<0.001)$ inhibin. A less pronounced, non-significant, correlation existed between LH and serum inhibin $(r=-0.48)$ and no relation existed between LH and testicular inhibin $(r=-0 \cdot 16)$. No significant correlations were obtained for serum LH or FSH with serum testosterone $(r=-0.01-0.27)$ and between intratesticular testosterone and intratesticular inhibin $(r=-0 \cdot 09)$. A significant correlation was found between testicular inhibin bioactivity and serum inhibin immunoreactivity $(r=0.77, P<0.001)$. Among rats receiving a testosterone implant, significant correlations were found only between serum inhibin and LH $(r=-0.58, P<0.01)$ or FSH $(r=-0.47, P<0.05)$.

\section{Discussion}

The present investigation demonstrates that the progressive elimination of Sertoli cells and spermatogenesis induced by increasing doses of glycerol administered by intratesticular injection was associated with a corresponding decrease in testicular inhibin bioactivity. Glycerol doses of $25 \mu \mathrm{l}, 100 \mu \mathrm{l}$ and $400 \mu \mathrm{l}$ lowered testicular inhibin activity by $24 \%, 68 \%$ and $90 \%$, respectively.

These findings suggest that inhibin is produced in the Sertoli cell and are in agreement with previous data obtained in vitro (Steinberger \& Steinberger, 1976; LeGac \& de Kretser, 1982) and in-vivo experiments (de Jong \& Sharpe, 1977; Au et al., 1984, 1986). Peripheral concentrations of immunoreactive inhibin were reduced by $10 \%, 25 \%$ and $57 \%$, respectively, with increasing doses of glycerol. Decreased testicular activity of inhibin was therefore associated with a reduction in serum inhibin levels, suggesting that peripheral concentrations of inhibin do reflect the intratesticular levels of inhibin. De Kretser et al. (1987) have reported that cryptorchidisminduced decrease of testicular inhibin levels was associated with a drop in circulating inhibin concentrations.

In the present study the testicular inhibin activity was reduced to a greater extent than were the serum inhibin concentrations. This difference could be due to the completely different assay systems used to measure testicular and serum inhibin values and may reflect the presence of inhibin molecules with different biological and immunological activities (Robertson et al., 1988). The gradual glycerol-induced decreases in inhibin activity in the present study were accompanied by serum FSH increments of $28 \%, 45 \%$ and $326 \%$, respectively, above control. These findings suggest a role of testicular and peripheral inhibin in the feedback regulation by inhibin (Main et al., 1978; Baker et al., 1981; Tsonis \& Sharpe, 1986). Our observations are in agreement with those of Au et al. $(1983,1987)$ who reported elevation of serum concentrations of FSH and reduction of testicular inhibin activity after heat treatment of the testes or the induction of cryptorchidism. 
In the $25 \mu \mathrm{l}$ and $100 \mu \mathrm{l}$ glycerol groups, selective elevation of serum FSH concentrations occurred but no changes were found in serum concentrations of $\mathrm{LH}$ and testosterone or the intratesticular testosterone concentrations. These results suggest that the normal endogenous testosterone values were apparently unable to prevent the elevation of FSH. In contrast, the selective elevation of FSH was closely related to the inhibin concentrations. Based on these findings it is suggested that inhibin is more important than testosterone for FSH feedback regulation.

Several reports have demonstrated that low to normal serum concentrations of testosterone, administered immediately after castration by injections or via Silastic implants, were associated with the abolition of the post-castration elevation of serum LH and FSH values (Swerdloff \& Walsh, 1973; Decker et al., 1981; Conne et al., 1982; Steiner et al., 1982). A similar observation was made in the present investigation in that low to normal serum testosterone values provided by Silastic implants completely blocked the elevation of serum FSH after injection of glycerol. The same mode of administration of testosterone also blocked the rise of FSH induced by heat treatment of the testis (Aafjes et al., 1978). Removal of Leydig cells by treatment with ethane dimethane sulphonate, leading to an immediate decline in serum testosterone concentrations, elicited a marked elevation of LH and FSH values (Bartlett et al., 1986; Jackson et al., 1986; O'Leary et al., 1986). These results strongly support a role for testosterone in the control of FSH but FSH concentrations do not attain those found in castrated rats. In other experiments when ethane dimethane sulphonate was given to cryptorchid rats in which FSH values are already elevated and inhibin concentrations are low (Au et al., 1983) the fall in testosterone results in FSH levels reaching the castrate range (O'Leary et al., 1986).

The Silastic implants containing testosterone provide constant testosterone concentrations compared to the pulsatile secretion of testosterone in the normal rat (Steiner et al., 1982). Therefore, the suppressive effects of testosterone implants on FSH observed in the present study, and by others, may not reflect the physiological situation as previously reported for LH (Damassa $e t$ al., 1976). Proof of our speculation, however, requires further investigations; for example, evaluation of the FSH response to pulsatile administration of testosterone in rats after induction of spermatogenic damage.

All testes from rats bearing a testosterone implant contained less than $25 \%$ of the inhibin values seen in the untreated control testis and were associated with lower serum inhibin concentrations. The decrease in testicular inhibin concentration occurred in the presence of normal or elevated serum concentrations of FSH and a reduction to 6-25\% of intratesticular testosterone concentrations. The drastically lowered availability of testosterone in the present study might therefore have compromised inhibin secretion by the Sertoli cell, suggesting that inhibin, at least in part, could be regulated at the testicular level. On the other hand, in intact rats treated with testosterone implants, testicular inhibin content remained unaltered despite a reduction of serum FSH concentrations by approximately $30-50 \%$ and of intratesticular testosterone concentrations by about 85-95\% (Au et al., 1985) whilst testicular inhibin production appeared testosterone-dependent. Production of inhibin by the testis, however, was not determined in the present investigation.

FSH has been shown to stimulate inhibin secretion from cultured Sertoli cells (LeGac \& de Kretser, 1982) and in hypophysectomized rats (Steinberger, 1981; Au et al., 1985). In the present investigation, in rats without a testosterone implant, the decreasing testicular inhibin activity paralleled the rise of serum FSH in the presence of similar intratesticular testosterone concentrations (see Fig. 1). It would therefore appear that FSH and/or testosterone did not stimulate inhibin in the glycerol-injected testis although $40-95 \%$ of seminiferous tubules still contained Sertoli cells as inferred from our previous study (Weinbauer et al., 1987). This finding, at least in part, may be explained by the partial disappearance of Sertoli cells in these testes. However, a further decrease in testicular inhibin production in the presence of similarly elevated serum FSH concentrations 1 and 2 weeks after heat treatment of the testis has also been found by others (Au et al., 1987). This observation could indicate that the activity and/or production of inhibin in the seminiferous tubules is also influenced by the status of the germinal epithelium rather than by FSH alone. 
In summary, the present investigations suggest that the dissociation of FSH feedback from that of LH may be predominantly related to inhibin. Our findings also indicate that testicular inhibin activity could partly be under local control of the testis.

We thank Martina Czichowsky, Reinhild Sandhowe and Martin Heuermann for technical assistance and Bärbel Dinkhoff for secretarial help.

\section{References}

Aafjes, J.H., Vreeburg, J.M. \& Schenck, R.E. (1978) Serum gonadotropins in rats after castration or heat treatment of the testes. Acta endocr., Copenh. 88, 260-273.

Au, C.L., Robertson, D.M. \& de Kretser, D.M. (1983) In vitro bioassay of inhibin in testes of normal and cryptorchid rats. Endocrinology 112, 239-244.

Au, C.L., Robertson, D.M. \& de Kretser, D.M. (1984) An in-vivo method for estimating inhibin production by adult rat testis. J. Reprod. Fert. 71, 259-265.

Au, C.L., Robertson, D.M. \& de Kretser, D.M. (1985) Effects of hypophysectomy and subsequent FSH and testosterone treatment on inhibin production by adult rat testes. J. Endocr. 105, 1-6.

Au, C.L., Irby, D.C., Robertson, D.M. \& de Kretser, D.M. (1986) Effects of testosterone on testicular inhibin and fluid production in intact and hypophysectomized adult rats. J. Reprod. Fert. 76, 257-266.

Au, C.L., Robertson, D.M. \& de Kretser, D.M. (1987) Changes in testicular inhibin after a single episode of heating of rat testes. Endocrinology 120,973-977.

Baine, J. \& Keene, J. (1975) Further evidence for inhibin: changes in serum LH and FSH after X-irradiation of rat testes. J. Endocr. 66, 279-280.

Baker, H.W.G., Eddie, L.W., Hudson, B., Keogh, E.J. \& Niall, H.D. (1981) Assays of inhibin. In Intragonadal Regulation of Reproduction, pp. 193-228. Eds P. Franchimont \& C. P. Channing. Academic Press, London.

Bartlett, J.M.S., Kerr, J.B. \& Sharpe, R.M. (1986) The effect of selective destruction and regeneration of rat Leydig cells on the intratesticular distribution of testosterone and morphology of the seminiferous epithelium. J. Androl. 7, 240-253.

Collins, P.M., Collins, W.P., McNeilly, H.S. \& Tsang, W.N. (1978) Plasma FSH, LH and testosterone levels in the male rat during degeneration of germinal epithelium caused by severe heat treatment or ligation of the vasa efferentia. J. Reprod. Fert. 54, 285-291.

Conne, B.S., Scaglioni, S., Lang, U., Sizonenko, P.C. \& Aubert, M.L. (1982) Pituitary receptor sites for gonadotropin-releasing hormone: effect of castration and substitutive therapy with sex steroids in the male rat. Endocrinology 110, 70-79.

Damassa, D.A., Kobashigawa, D., Smith, E.R. \& Davidson, J.M. (1976) Negative feedback control of LH by testosterone: a quantitative study in male rats. Endocrinology 99, 736-742.

Decker, M.H., Loriaux, D.L. \& Cutler, G.B. (1981) A seminiferous tubule factor is not obligatory for regulation of plasma follicle-stimulating hormone in the rat. Endocrinology 108, 1035-1039.

de Kretser, D.M., Burger, H.G. \& Bremner, W.J. (1983)
Control of LH and FSH secretion. In The Pituitary and the Testis, Clinical and Experimental Studies, pp. 12 43. Eds D. M. de Kretser, H. G. Burger \& B. Hudson. Springer Verlag, Berlin.

de Kretser, D.M., Irby, D.C., McLachlan, R. \& Robertson, D.M. (1987) The measurement of circulating inhibin levels in the male rat: changes after castration and cryptorchism. Proc. Endocr. Soc. Austr. 30, 39, Abstr.

de Jong, F.H. \& Sharpe, R.M. (1977) Gonadotrophins, testosterone and spermatogenesis in neonatally irradiated male rats: evidence for a role of the Sertoli cell in follicle-stimulating hormone feedback. $J$. Endocr. $75,209-219$.

Huang, H.F.S., Zaidi, P. \& Nieschlag, E. (1984) Alteration of the pituitary-testicular feedback during germinal involution in the vitamin A deficient rat. $J$. Endocr. 100, 33-41.

Jackson, A.E., O'Leary, P.C., Ayers, M.M. \& de Kretser, D.M. (1986) The effects of ethylene dimethane sulphonate (EDS) on rat Leydig cells: Evidence to support a connective tissue origin of Leydig cells. Biol. Reprod. $35,425-437$.

LeGac, F. \& de Kretser, D.M. (1982) Inhibin production by Sertoli cell cultures. Molec. cell. Endocrinol. 28, 487-498.

Main, S.J., Davies, R. \& Setchell, B.P. (1978) The evidence that inhibin must exist. J. Reprod. Fert., Suppl. 26, 3-14.

Mason, A.J., Hayflick, J.S., Ling, N., Esch, F., Ueno, N., Ying, S.Y., Guillemin, R., Niall, H. \& Seeburg, P.H. (1985) Complementary DNA sequences of ovarian follicular inhibin show precursor homology with transforming growth factor- $\beta$. Nature, Lond. 318, 659-663.

Morris I.D. \& Jackson, C.M. (1978) Gonadotrophin changes in male rats following a sterilizing dose of a-chiorohydrin. Int. J. Androl. 1, 86-95.

O'Leary, P., Jackson, A.E., Averill, S. \& de Kretser, D.M. (1986) The effects of ethane dimethane sulphonate on bilaterally cryptorchid rat testes. Molec. cell. Endocrinol. 45, 183-190.

Rich, K.A., Kerr, J.B. \& de Kretser, D.M. (1979) Evidence for Leydig cell dysfunction in rats with seminiferous tubule damage. Molec. cell. Endocrinol. 13, 123-135.

Robertson, D.M., Foulds, L.M., Leversha, L., Morgan, F.J., Hearn, M.T.W., Burger, H.G., Wettenhall, R.E.H. \& de Kretser, D.M. (1985) Isolation of inhibin from bovine follicular fluid. Biochem. Biophys. Res. Commun. 126, 220-226.

Robertson, D.M., Hayward, S., Irby, D., Jacobsen, J., Clarke, C., McLachlan, R.I. \& de Kretser, D.M. (1988) Radioimmunoassay of rat serum inhibin: changes after PMSG-stimulation and gonadectomy. Molec. cell. Endocrinol. 58, 1-8. 
Schürmeyer, Th., Wickings, E.J., Freischem, C.W. \& Nieschlag, E. (1983) Saliva and serum testosterone following oral testosterone undecanoate administration in normal and hypogonadal men. Acta endocr., Copenh. 100, 456-462.

Steinberger, A. (1981) Regulation of inhibin secretion in the testis. In Intragonadal Regulation of Reproduction, pp. 283-298. Eds P. Franchimont \& C. P. Channing. Academic Press, London.

Steinberger, A. \& Steinberger E. (1976) Secretion of an FSH-inhibiting factor by cultured Sertoli cells. Endocrinology 99, 918-921.

Steiner, R.A., Bremner, W.J. \& Clifton, D.K. (1982) Regulation of luteinizing hormone pulse frequency and amplitude by testosterone in the adult male rat. Endocrinology 111, 2055-2061.

Swerdloff, R.S. \& Walsh, P.C. (1973) Testosterone and oestradiol suppression of LH and FSH in adult male rats: duration of castration, duration of treatment and combined treatment. Acta endocr., Copenh. 73, 11-21.
Tsonis, C.G. \& Sharpe, R.M. (1986) Dual control of follicle-stimulating hormone. Nature, Lond. 321, 724-725.

Tsonis, C.G., McNeilly, A.S. \& Baird, D.T. (1986) Measurement of exogenous and endogenous inhibin in sheep serum using a new and extremely sensitive bioassay for inhibin based on inhibition of ovine pituitary FSH secretion in vitro. J. Endocr. 110, 341-352.

Weinbauer, G.F., Galhotra, M.M. \& Nieschlag, E. (1985) Focal testicular destruction following intratesticular injection of glycerol. Int. J. Androl. 8, 365-375.

Weinbauer, G.F., Drobnitzky, F., Galhotra, M.M. \& Nieschlag, E. (1987) Intratesticular injection of glycerol as a model for studying the quantitative relationship between spermatogenic damage and serum FSH. J. Endocr. 115, 83-90.

Received 21 December 1987 